\title{
Predation by Erythemis nymphs (Odonata) on Chironomidae (Diptera) and Elmidae (Coleoptera) in different conditions of habitat complexity
}

Predação de ninfas de Erythemis (Odonata) sobre Crironomidae (Diptera) e Elmidae (Coleoptera) em diferentes condiçóes de complexidade do habitat

João Ânderson Fulan ${ }^{1}$ and Marcelo Rodrigues dos Anjos ${ }^{1}$

${ }^{1}$ Universidade Federal do Amazonas - UFAM, Rua 29 de agosto, 786, CEP 69800-000, Humaitá, AM, Brazil

e-mail: joaofulan@hotmail.com; anjos.ufam@gmail.com

\begin{abstract}
Aim: The goal of this study was to analyze the effects of predation by nymphs of Erythemis Hagen, 1861 on Elmidae and Chironomidae and to check if the presence and the architecture of aquatic macrophytes may mediate this interaction. Methods: All prey as well as nymphs were captured near macrophytes in a small lagoon alongside a highway near Humaitá, Amazonas, Brazil. Twelve buckets were used in three different treatments: with Pistia stratiotes Linnaeus, 1753, with Salvinia auriculata Aublet and without macrophytes. Results: We found a mortality rate of $100 \%$ of Chironomidae and Elmidae larvae in the treatment without macrophytes. There was a greater survival of Elmidae compared to Chironomidae in the treatments with P. stratiotes and S. auriculata; however, there was a greater survival of both preys on treatment with $P$. stratiotes. Conclusions: We conclude that the presence of macrophytes decreased the efficiency of predation of Erythemis nymphs under experimental conditions. The architecture of macrophytes affected predation as macrophytes with longer roots and with greater habitat complexity promoted a greater survival of prey.
\end{abstract}

Keywords: dragonflies; lake; macrophyte.

Resumo: Objetivo: Os objetivos deste trabalho foram analisar os efeitos da predação de ninfas de Erythemis Hagen, 1861 sobre Elmidae e Chironomidae, e verificar se a presença e a arquitetura de macrófitas podem mediar essa interação. Métodos: Todas as presas bem como as ninfas foram capturadas em uma pequena lagoa lateral a rodovia BR319 que passa pelo município de Humaitá, Amazonas. Doze baldes foram utilizados nos três diferentes tratamentos: Pistia stratiotes Linnaeus, 1753, Salvinia auriculata Aublet e sem macrófitas. Dez larvas de Coleoptera, dez larvas de Chironomidae e duas ninfas de Erythemis foram utilizadas em cada tratamento. Resultados: Houve mortalidade de $100 \%$ das larvas de Chironomidae e Elmidae no tratamento sem macrófitas. Houve maior sobrevivência de Elmidae em comparação a Chironomidae nos tratamentos com P. stratiotes e $S$. auriculata, porém houve sobrevivência maior de ambas as presas no tratamento com P. stratiotes. Conclusóes: A presença de macrófitas diminuiu a eficiência de predação das ninfas de Erythemis em condiçóes experimentais. A arquitetura da macrófita afetou a predação, sendo que raízes mais longas e com maior complexidade do habitat propiciaram uma maior sobrevivência das presas.

Palavras-chave: libélulas; lago; macrófita. 


\section{Introduction}

The choice of habitat by the prey is directly related to the risk of predation (Hossie \& Murray, 2010; Figueiredo et al. 2015). More complex habitats as macrophytes have a lower predation risk, and therefore, near these plants there is high densities of small fish and other macroinvertebrates (Webster \& Hart, 2004; Pelicice et al., 2005; Pelicice \& Agostinho, 2006; Cunha et al. 2012; Figueiredo et al., 2013). This positive relationship between associated fauna and high density due to the higher habitat complexity was observed by several authors (Jeffries 1993; Pelicice \& Agostinho 2006).

In Brazil there is high species diversity of macrophytes, including submerged rooted, rooted floating and floating forms (Esteves, 2011). Among the floating plants, two stand out because of their high incidence: Pistia stratiotes Linnaeus, 1753 and Salvinia auriculata Aublet. Although both are floating plants, they differ in the length and diameter of roots, being larger and wider in P. stratiotes compared to S. auriculata (Joly, 1987). A typical $P$. stratiotes has a root length around $15-20 \mathrm{~cm}$, while $S$. auriculata around $2-10 \mathrm{~cm}$ (Joly, 1987). Nymphs of Odonata are recorded frequently in P. startiotes and S. auriculata (Escher \& Lounibos, 1993; Fulan et al., 2011)

The nymphs of Odonata are known to be one of the major predators in aquatic ecosystems, feeding on any prey compatible with their size (Corbet, 1999). According to Soares et al. (2003), Odonata nymphs can feed even on post-larval fish like American catfish Ictalurus punctatus (Rafinesque, 1818), Tilápia Oreochromis niloticus (Linnaeus, 1758) and Curimba Prochilodus lineatus (Valenciennes, 1847). However, the preys recorded more often in the stomach contents of the nymphs are macroinvertebrates, mainly Chironomid larvae (Hamada \& Oliveira, 2003) and Coleoptera larvae (Thompson, 1978); in this case when the Odonata are already in their final instar.

Chironomid larvae are the most abundant macroinvertebrate in the sediment and on macrophytes (Nessimian \& Carvalho, 1998). They are herbivores and/or detritivorous and generally benthic and sedentary, but may also exhibit a swimmer behavior (Takagi et al., 2005). This swimmer behavior was observed in Chironomus both in the first instar (Oliver, 1971) and the last instar (Moon, 1940; Berg, 1950). Elmidae larvae (Coleoptera), in contrast to Chironomidae, do not show a swimmer behavior at any stage of their cycle life (White, 1983). Their larvae live crawling on consolidated sediments as well as on small rocks or even macrophytes from lotic environments (most species), but may even occur in small ponds with stagnant water (Mccafferty, 1983; Stehr, 1991).

This difference in architecture is important for their colonization by macroinvertebrates. A comparative study of $P$. stratiotes and Salvinia showed that the abundance of associated macroinvertebrates was higher in P. stratiotes compared to Salvinia and that this difference was caused by greater habitat complexity observed in P. stratiotes (Torretta et al., 2006).

In this context, the aim of this study was to investigate the effects of habitat complexity provided by the roots of $P$. stratiotes and $S$. auriculata on predation of Chironomidae (Diptera) and Elmidae (Coleoptera) by Erythemis nymphs (Odonata).

\section{Material and Methods}

All Diptera and Coleoptera, the nymphs of Erythemis and macrophytes (P. stratiotes and S. auriculata) were sampled on a side lagoon BR319 (7'37'54" S and 6304' $\left.47^{\prime \prime} \mathrm{W}\right)$ near the city of Humaita, Amazonas State, Brazil. The experiment was conducted in the Limnology Laboratory of the Federal University of Amazonas. Twelve buckets with 20 liters of water each were used in the experiment. Treatments were performed with the macrophyte $P$. stratiotes, $S$. auriculata and without macrophytes. Four replications were carried out for each treatment. The macrophytes were washed before the experiment to completely remove all associated macroinvertebrates. A 50\% surface area cover of water was ensured in the buckets where the floating macrophytes were placed. The standardized length of the roots of $P$. stratiotes and $S$. auriculata were 15 and $5 \mathrm{~cm}$, respectively.

Ten Chironomid larvae and ten of Coleoptera were placed in each bucket 24 hours before the start of the experiment for enable adaptation. The Erythemis nymphs were maintained for 24 hours without food and after this period two individuals were placed in each bucket.

The laboratory temperature was maintained between 26 and $32^{\circ} \mathrm{C}$. The experiment was started at 10:00 am on 15 January 2013 and ended at 10:00 am on 17 January 2013. The macroinvertebrates were obtained from the Limnology Laboratory of the Institute of Education, Agriculture and Environment. A Chi-square test was performed to investigate if the frequency of predation differed among treatments. 


\section{Results and Discussion}

All Chironomidae and Elmidae were preyed in the treatment without macrophytes in all four replicates (Figure 1). A Chi-square test revealed significant difference in the frequency of predation of Erythemis on Elmidae $\left(X^{2}=541.81 ; p=0.05 ; d f=2\right.$; Table 1$)$ and Chironomid $\left(X^{2}=61.80 ; p=0.05 ; d f=2\right.$; Table 2 ) between the treatments. Tables 1 and 2 show that macrophytes are important refuges for macroinvertebrates against their predators as observed by other researchers (Padial et al., 2009; Cunha et al., 2012; Kovalenko et al., 2012). In addition, in the laboratory experiment it was registered a significant difference in survival of Elmidae and Chironomidae according to the species of macrophyte. There was a higher survival of Elmidae and Chironomidae in the treatment with P. stratiots compared to $S$. auriculata. This higher survival on the treatment with $P$. stratiotes likely occurred due to difference in the plant architecture that modifies its complexity habitat. Kovalenko et al. (2012) argued that habitat complexity is one of

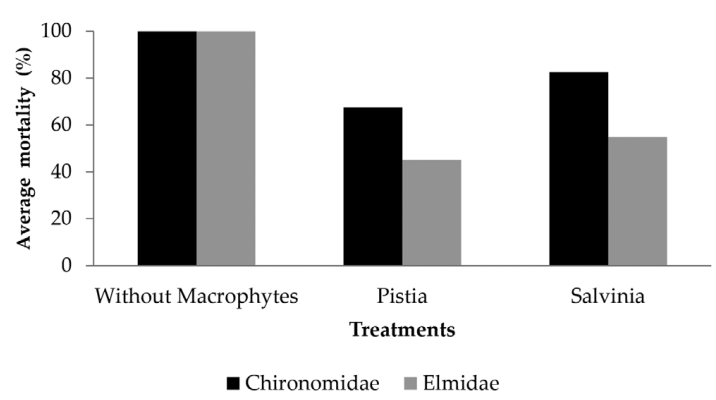

Figure 1. Average predation rate of Chironomidae and Elmidae in the presence of Erythemis nymphs in treatments with $P$. stratiotes, $S$. auriculata and without aquatic macrophytes.

Table 1. Predation on Elmidae in the differents treatments.

\begin{tabular}{lccc}
\hline \multicolumn{1}{c}{ Treatment } & Preyed & Non-preyed & TOTAL \\
\hline Control & 40 & 0 & 40 \\
P. stratiotes & 22 & 18 & 40 \\
S. auriculata & 18 & 22 & 40 \\
TOTAL & 80 & 40 & 120 \\
\hline
\end{tabular}

Table 2. Predation on Chironomid in the differents treatments.

\begin{tabular}{lccc}
\hline \multicolumn{1}{c}{ Treatment } & Preyed & Non-preyed & TOTAL \\
\hline Control & 40 & 0 & 40 \\
P. stratiotes & 13 & 27 & 40 \\
S. auriculata & 7 & 33 & 40 \\
TOTAL & 60 & 60 & 120 \\
\hline
\end{tabular}

the most important factors in structuring biotic assemblages and affects predator-prey interactions, despite the lack of knowledge about mechanism. According to the authors, it is also very difficult to compare different macrophytes species as P. stratiots and $S$. auriculata.

P. stratiotes exhibits a distinct architecture when compared with $S$. auriculata, especially regarding its roots (Joly, 1987). Whereas S. auriculata shows a horizontal rhizome formed by a colony of branches, a pair of floating sheets and modified leaves that have similar function to a small root (Croxdale, 1978, 1979, 1981; Room, 1983), P. stratiotes shows floating leaves in the form of rosette, which can be alone and extensive adventitious root system (Langeland \& Burks, 1998). This difference in architecture, especially with regard to the length and diameter of the $S$. auriculata and P. stratiotes root, can affect the availability of refuges. Torretta et al. (2006) observed a greater abundance of macroinvertebrates along the roots of $P$. stratiotes compared to $S$. auriculata, mainly due to the greater habitat complexity provided by $P$. stratiotes. Padial et al. (2009) also reported that the increase in complexity of the habitat due to plant architecture decreased benthic predation by other predators such as fish, similar to that observed in this work.

Our analysis clearly suggests that the shelters provided by the roots of macrophytes increased the survival of prey, because while in the treatments with macrophytes some larvae of Chironomidae and Elmidae survived, in the treatment without macrophytes all prey were consumed, without exception and in all replicates. These results are in line with the findings of Parsons \& Matthews (1995) that macrophyte roots form important refuges for macroinvertebrates. The survival of Chironomidae and Elmidae in the treatments with macrophytes likely occurred because their roots provided refuges for the prey, which decreased the efficiency of detection of the prey by the Odonata nymphs. According to Corbet (1999), normally larvae of Odonata detect preys by their movement and caught then alive. However, there was a higher predation rate on the treatments with $S$. auriculata when compared to P. stratiotes.

We conclude that the presence of floating aquatic macrophytes decreased the predation efficiency of Erythemis nymphs in artificial conditions. The macrophyte architecture affected the predation, and longer roots and more habitat complexity provided a greater survival of prey. 


\section{Acknowledgements}

This work was funded by Conselho Nacional de Desenvolvimento Científico e Tecnológico (Proc. 471465/2011-9).

\section{References}

BERG, C.O. Biology of certain Chironomidae reared from Potamogeton. Ecological Monographs, 1950, 20(2), 83-101. http://dx.doi.org/10.2307/1943546.

CORBET, P.S. Dragonflies: behavior and Ecology. New York Cornell: University Press, 1999.

CROXDALE, J.G. Salvinia leaves. I. Origin and early differentiation of floating and submerged leaves. Canadian Journal of Botany, 1978, 56(16), 19821991. http://dx.doi.org/10.1139/b78-237.

CROXDALE, J.G. Salvinia leaves. II. Morphogenesis of the floating leaf. Canadian Journal of Botany, 1979, 57(19), 1951-1959. http://dx.doi.org/10.1139/ b79-245.

CROXDALE, J.G. Salvinia leaves. III. Morphogenesis of the submerged leaf. Canadian Journal of Botany, 1981, 59(11), 2065-2072. http://dx.doi.org/10.1139/b81268.

CUNHA, E.R., THOMAZ, S.M., MORMUL, R.P., CAFOFO, E.G. and BONALDO, A.B. Macrophyte structural complexity influences spider assemblage attributes in wetlands. Wetlands, 2012, 32(2), 369377. http://dx.doi.org/10.1007/s13157-012-0272-1.

ESCHER, R.L. and LOUNIBOS, L.P. Insect associates of Pistia stratiotes (Arales: Araceae) in Southeastern Florida. The Florida Entomologist, 1993, 76(3), 473500. http://dx.doi.org/10.2307/3495648.

ESTEVES, F.A. Fundamentos de Limnologia. Rio de Janeiro: Interciência, 2011.

FIGUEIREDO, B.R.S., MORMUL, R.P. and BENEDITO, E. Nonadditive effects of macrophyte cover and turbidity on predator-prey interactions involving an invertivorous fish and different prey types. Hydrobiologia, 2013, 716(1), 21-28. http:// dx.doi.org/10.1007/s10750-013-1540-7.

FIGUEIREDO, B.R.S., MORMUL, R.P. and THOMAZ, S.M. Swimming and hiding regardless of the habitat: prey fish do not choose between a native and a non-native macrophyte species as a refuge. Hydrobiologia, 2015, 746(1), 285-290. http:// dx.doi.org/10.1007/s10750-014-2096-x.

FULAN, J.A., DAVANSO, R.C.S. and HENRY, R. A profundidade como fator determinante na variação anual da densidade dos macroinvertebrados associados à Salvinia auriculata Aublet. Revista Brasileira de Biociências, 2011, 9, 214-219.

HAMADA, N. and OLIVEIRA, S.J. Food items of larvae of Rimanella arcana (Needham, 1933) (Odonata:Amphipterygidae) in Central Amazonia, Brazil. Entomotropica, 2003, 18(2), 153-155.
HOSSIE, T.J. and MURRAY, D.L. You can't run but you can hide: refuge use in frog tadpoles elicits densitydependent predation by dragonfly larvae. Oecologia, 2010, 163, 395-404.

JEFFRIES, M. Invertebrate colonization of artificial pondweeds of differing fractal dimension. Oikos, 1993, 67, 142-148.

JOLY, A.B. Botânica: introdução à taxonomia vegetal. São Paulo: Editora Nacional, 1987.

KOVALENKO, K.E., THOMAZ, S.M. and WARFE, D.M. Habitat complexity: approaches and future directions. Hydrobiologia, 2012, 685(1), 1-17. http:// dx.doi.org/10.1007/s10750-011-0974-z.

LANGELAND, K.A. and BURKS, K.C. Identification \& biology of non-native plants in Florida's natural areas. Gainesville: University of Florida, 1998.

MCCAFFERTY, W. Aquatic entomology: the fishermen's and ecologists' illustrated guide to insect and their relatives. Burlington: Jones and Bartlett Publishers, 1983.

MOON, H.P. An investigation of the movements of freshwater invertebrate faunas. Journal of Animal Ecology, 1940, 9(1), 76-83. http://dx.doi. org/10.2307/1428.

NESSIMIAN, J.L. and CARVALHO, A.L. Ecologia de insetos aquáticos. Rio de Janeiro: PPGE-UFRJ, 1998.

OLIVER, D.R. Life history of the Chironomidae. Annual Review of Entomology, 1971, 16(1), 211-230. http:// dx.doi.org/10.1146/annurev.en.16.010171.001235.

PADIAL, A.A., THOMAZ, S.M. and AGOSTINHO, A.A. Effects of structural heterogeneity provided by the floating macrophyte Eichhornia azurea on the predation efficiency and habitat use of the small Neotropical fish Moenkhausia sanctaefilomenae. Hydrobiologia, 2009, 624(1), 161-170. http://dx.doi. org/10.1007/s10750-008-9690-8.

PARSONS, J.K. and MATTHEWS, R.A. Analysis of the associations between macroinvertebrates and macrophytes in a freshwater pond. Northwest Science, 1995, 69(4), 265-275.

PELICICE, F.M. and AGOSTINHO, A.A. Feeding ecology of fishes associated with Egeria spp patches in a tropical reservoir, Brazil. Ecology Freshwater Fish, 2006, 15(1), 10-19. http://dx.doi.org/10.1111/ j.1600-0633.2005.00121.x.

PELICICE, F.M., AGOSTINHO, A.A. and THOMAZ, S.M. Fish assemblages with Egeria in a tropical reservoir: investigating the effects of plant biomass and diel period. Acta Oecologica, 2005, 27(1), 9-16. http://dx.doi.org/10.1016/j.actao.2004.08.004.

ROOM, P.M. Falling-apart as a lifestyle: the rhizome architecture and population growth of Salvinia molesta. Journal of Ecology, 1983, 17(2), 349-365. http://dx.doi.org/10.2307/2259719. 
SOARES, C.M., HAYASHI, C. and REIDEL, A. Predação de pós-larvas de curimba (Prochiloduslineatus, Valenciennes, 1836) por larvas de Odonata (Pantala, Fabricius, 1798) em diferentes tamanhos. Acta Scientiarum, 2003, 25(1), 95-100. http://dx.doi. org/10.4025/actascibiolsci.v25i1.2105.

STEHR, F.W. Immature insects. Iowa: Kendall/Hunt Publishing Company, 1991.

TAKAGI, S., KIKUCHI, E., DOI, H. and SHIKANO, S. Swimming behavior of Chironomus acerbiphilus larvae in Lake Katanuma. Hydrobiologia, 2005, 548(1), 153-165. http://dx.doi.org/10.1007/s10750005-5196-9.

TORRETTA, J.P., MULIERI, P.R., PATITUCCI, L.D., SANDER, V.A., RODRÍGUEZ, P.L. and SCHWEIGMANN, N. Winter survival of immature instars of Mansonia indubitans Dyar \& Shannon and Mansoniatitillans Walker (Diptera: Culicidae), in Buenos Aires, Argentina. Memorias do Instituto Oswaldo Cruz, 2006, 101(6), 591-596. http:// dx.doi.org/10.1590/S0074-02762006000600003. PMid:17072469.

WEBSTER, M.M. and HART, P.J.B. Substrate discrimination and preference in foraging fish. Animal Behaviour, 2004, 68(5), 1071-1077. http:// dx.doi.org/10.1016/j.anbehav.2004.04.003.

WHITE, R.E.P. Field guides beetles. New York: Houghton Mifflin Company, 1983.

Received: 16 September 2015 Accepted: 05 April 2016 